Т. В. Михальченко старший преподаватель

\title{
К ВОПРОСУ ОБ ЭТАПАХ ИЗУЧЕНИЯ ХУДОЖЕСТВЕННОГО СТИЛЯ БАРОККО
}

У статті здійснено огляд етапів реабілітації художнього стилю бароко, висвітлено стан вивчення проблеми та обгрунтовано ї̈ актуальність.

По мнению многих авторитетных ученых [5,7], понятия барокко, барочный вплоть до прошлого века хранили в своих самых обычных много- 
численных употреблениях коннотацию эксцентричности, странности, отсутствия здравого смысла. Только XX век принес существенный сдвиг в дело признания и реабилитации этого стиля. Но если в отношении барокко в архитектуре, живописи, музыке были высказаны вполне определенные суждения, то в литературном аспекте научно признанные критерии давали сбой, так как аналогии между различными видами искусства могут порождать противоречия и заблуждения. Таким образом, целый литературный пласт, которым пренебрегали, произведения, которые считали не заслуживающими внимания, противоречивыми, допускающими отклонения от правил, отмеченными незавершенностью или излишествами, на долгие годы исчезли из поля зрения литературной критики.

Необходимо прояснить противоречивые пункты, так как исторический аспект слова барокко (от истоков до наших дней) подразумевает многие семантические вариации, употребляется в различных видах искусства, в том числе и в литературе, имеет многочисленные нюансы употребления.

Слово барокко появилось в обиходе французского языка в I пол. XVI века как заимствование из португальского barrocco, что означало «жемчужина неправильной формы». На иберийском наречии еще с XIII века словом barrocca называли камень странной формы, что позже было перенесено и на жемчужины из морских раковин. Однако существует и другая предыстория, связанная со словом барокко. На Северо-Западе Индии, недалеко от португальской фактории Гоа, известного центра продажи жемчуга, есть город Барокия, который якобы и дал свое имя жемчужинам, их называли «жемчужинами Барокии», основным качеством которых было несовершенство формы.

Первое французское определение слова барокко может быть отнесено к «Краткому параллельному изложению французского и латинского языков» (1630) аббата Филибера Монэ. В статье «Жемчужина» автор пишет: «Жемчужина барокко - овальная, продолговатая и тонкая наощупь». В «Королевском словаре» П. Помея (1671) слово толкуется следующим образом: «Барокко - это жемчужина округлой формы, ровная с одного края, круглая с другого». Эти вариации обобщены А. Фюретьером в его «Универсальном словаре» (1690): «Барокко - это жемчужина несовершенной, округлой формы». Определение понятия барокко было зафиксировано в Словаре Французской Академии, в его первом издании, в 1694 году, которое подтверждало негативный оттенок слова: «Жемчужина несовершенной округлости».

Но вскоре эти формулировки входят в противоречие с более широким толкованием понятия. В своем «Этимологическом словаре» (1694) Менаж предлагает первую ассоциацию, достойную «блазона» (небольшой поэмы, жанра XVI века) или натюрморта, иронически сравнивая колье из нанизанных жемчужин с зубной челюстью: «Барокко - это жемчужины или зубы неодинаковой величины». 
В следующем XVIII веке открывается эра фигурального смысла и новой судьбы этого слова. Объем понятия постепенно расширяется, все чаще термин барокко используют для описания внешнего облика (портрета, черт лица), какой-нибудь странной, шокирующей мысли или нелепой выходки, поступка.

Расширение объема понятия впервые зафиксировано в Словаре Французской Академии (1740). Барокко употребляется в переносном, фигуральном смысле для выражения странности, неправильности, нелепости (мысли, высказывания, поступка, внешности).

Этот термин находит свое применение в различных видах искусства. В музыке странность и неправильность, иными словами барокко, проявляется в отсутствии гармонии, в перегруженности модуляциями и диссонансами, в сложности интонации. В архитектуре барокко характеризуется утратой использования форм круга и квадрата, причудливостью орнамента. В живописи - отсутствием правил пропорции и меры, подчиненностью лишь капризам творца.

В литературе нюанс странности, закрепленный за барокко, приобретает характер удаленности от правил общего порядка, отождествляется со стремлением к независимости, к фантастической эксцентричности. Так рождается понимание барокко как оппозиции классицизму, как стремление к освещению противоречий, как прорыв к свободе творческой фантазии. Co II половины XVIII века смысл понятия семантически сближается с «варварством», «средневековьем», «готикой», но выражает не исторически определенный стиль, а служит для обозначения «дурного вкуса», отличного от ясного и гармоничного античного стиля. Таким образом, «неправильный», «странный» барочный стиль расценивается как «дурной вкус», где отсутствуют правила пропорции, меры и гармонии, где все подчинено не определенным правилам, а фантазии автора.

Интерес к эпохе от царствования Карла IX до Людовика XIII пробуждается в I половине XIX века. Барочное искусство остается странным и безобразным, но сама эпоха становится модной, ее герои: Сен-Мар, Сирано де Бержерак, королева Марго, маршал д’Анкр, Марион Делорм и др. Впервые, начиная с 1830-х годов, прилагательное барочный употребляется в позитивном смысле. Поколение романтиков ищет у авторов, осужденных классицистами, истоки своих литературных новаций. Сент-Бев реабилитирует забытого Ронсара, восхищается поэзией эпохи Людовика XIII. Т. Готье отдает дань блистательным стихам Теофиля де Вио и Сент-Амана, вариациям тона и стилю, от возвышенного до комического.

Но в официальной истории этот литературный период не имеет названия, его привязывают то к «позднему Возрождению», то называют «классическим романтизмом». Авторы этого периода объединены под общим названием: «неправильные, независимые, изолированные». Но, так или иначе, этот период находится под абсолютной референцией классицизма. 
Модель такого видения литературной эпохи дана в «Истории французской литературы» Г. Лансона, где главы названы соответствующим образом. Конец XVI века озаглавлен: «Переход к классицистической литературе». XVII век Лансон разбивает на четыре фазы: подготовка к шедеврам; первое поколение классицистов; великие классицисты; конец века классицизма. И лишь небольшое отступление между Малербом и зачинателями классицизма (Гезом де Бальзаком, Декартом и Шапленом) посвящено настроениям в литературе, которые охарактеризованы автором как «невероятная сумятица противостояний, противоречий и отклонений». Это определение надолго закрепило за писателями этого направления формулировку «отставшие и сбившиеся с пути» $[2,18]$.

Правда, в «Гротесках» (1844) Т. Готье делает попытку реабилитировать некоторых барочных авторов. Говоря о репутации писателя, об ореоле славы, Готье замечает странную вещь, отмечая, что часто после смерти ореол писателя, прославленного при жизни, меркнет, а звезда того, кто находился в тени, загорается новым светом: «Для одних последующие века - темная ночь, для других - восходящая заря» $[1,7]$. В его размышлениях о творчестве писателей барокко уже содержится попытка дать отличительные черты барочного стиля, тем самым подготавливается плацдарм для будущих историков литературы.

Отталкиваясь от серии гравюр Ж. Калло (1593-1635), французского графика, под общим названием «Гротески», Т. Готье восхваляет художников, у которых «мелок оживляет тысячи барочных фантазий, не заботясь о чистоте линий». Так слово гротески становится эквивалентом слова арабески. Готье рассматривает творчество пяти или шести писателей, отвергнутых классицистами (Сент-Аман, Т. Де Вио, П. Скаррон, С. Де Бержерак). В 1831 году Ш. Нодье публикует большую статью о создателе жанра «воображаемых путешествий» Сирано де Бержераке (1619-1655), авторе «Комической истории Государств и империй Луны».

Все эти авторы не были собраны в одну группу по критериям, характеризующим барокко. Задачей романтиков являлась не столько реабилитация имен авторов, сколько стремление подкорректировать историю литературы, одобрить эстетику «странности», «причудливости», которую новая романтическая школа взяла за основной принцип своей поэтики.

До конца XIX века в отношении барокко не существует требований научной пунктуальности. Большинство теоретиков искусства придерживаются старых взглядов, основанных на возведенной в норму оппозиции между двумя стилями: иррациональным, экстравагантным барокко и рациональным, уравновешенным классицизмом.

Пока французы пытались дать более точное лингвистическое определение «странности» барокко, немецкие историки искусства привнесли в европейские языки новые размышления об эстетической природе этого феномена. 
В последнее десятилетие XIX века в Италии и Германии в связи с пробуждением националистических тенденций вспыхивает интерес к мифам и национальным преданиям и легендам. Это влечет за собой и некий пересмотр эстетических суждений о предыдущих эпохах. Якоб Бурхард, профессор истории и цивилизации, в своих трудах, сравнивая барочную архитектуру с архитектурой эпохи Возрождения, характеризует барокко как упадок Ренессанса, как форму декаданса в искусстве этой эпохи. Его ученик, швейцарский историк искусств Г. Вельфлин (1864-1945), совершает решительный переворот в оценке и интерпретации барочного искусства. Он исследует историю стилей в искусстве. В 1886-8 гг., живя в Италии и изучая итальянское искусство, он работает над научным трудом по реабилитации барокко «Ренессанс и барокко». Позже, через 20 лет, он опубликует свой главный труд «Фундаментальные принципы истории искусств» (1915).

Вопреки авторитету своего учителя, Вельфлин высказывает мнение о трансформации, основываясь на трех принципах:

- эффекте живописности, красочности (приоритет кажущейся видимости, светотени, беспорядочности, неуловимости);

- эффекте массы (акцент на массивность, тяжесть, вплоть до потери формы, выпуклость, разнообразие элементов);

- эффекте движения (чувство направления, стремление ввысь, неравномерное распределение мотивов, ритмическая, а не метрическая последовательность, напряженность пропорций).

Это был переворот в искусствоведении. Там, где раньше, опираясь на классический идеал, историки искусства находили «убожество форм» (Винкельман), Вельфлин отмечает впечатляющую игру видимости, находя в экстравагантных контурах модель создания неосязаемой иллюзии, колеблющейся между небом и землей.

Это был новый взгляд на барочное искусство, которое долгое время рассматривалось учеными как упадок, вырождение искусства Ренессанса. Вельфлин в процессе своих исследований приходит к идее трансформации. Барокко есть стиль в искусстве, а также исторический период. Этот стиль рассматривается им как трансформация или переход в новую фазу искусства Ренессанса. Новая эпоха порождает новые формы. По мнению Вельфлина, великие мастера позднего Возрождения сами создают искусство барокко.

В своем исследовании автор пытается постичь различия между классикой и барокко. Основы современных размышлений о барокко в литературе основаны на его открытиях. Останавливаясь на методических несоответствиях примеров рисунка, живописи, гравюры, скульптуры Возрождения (около 1500 гг.) и следующим веком (конец XVI - начало XVII вв.), он предлагает характеризовать развитие искусства, исходя из следующих положений: 
1) Переход от линейного к живописному. Речь идет о том, что свойства элементов представлены в искусстве Возрождения линейно, одномерно, линии и контуры предметов ясно просматриваются. В живописном искусстве барокко они просматриваются, благодаря их массе или пятнам. В классическом искусстве предметы даны в стабильной реальности, в их изначальной неизменности, в барочном искусстве - они неустойчивы, зыбки;

2) Переход от представления плана к представлению глубины. Эта оппозиция касается использования пространства и отношения между частями произведения. В классическом искусстве части расположены в параллельных планах, барокко следует взгляду вперед и назад. В первом случае пространство ограничено, разделено на горизонтальные пласты, фигуры выстроены прямолинейно. Во втором - пространство продолжается вглубь, фигуры и элементы выстроены по диагонали;

3) Переход от закрытой формы к форме открытой. Это оппозиция между симметрией и асимметрией, равновесием и диспропорцией. Впечатление классической ясности и безмятежности уступает место барочным диссонансам. В классическом искусстве эпизод или сцена действительности даны в естественной завершенности, в барочном искусстве кадр или сцена изображены незавершенно, произведение представляет собой фрагмент видимой реальности, случайно схваченный творцом.

Благодаря исследованиям Вельфлина, барокко было поднято до высот классики. Это искусство рассматривается им не как радикальный разрыв с Ренессансом, а как внутренняя эволюция форм. Стиль является выражением эпохи. И совершенно очевидно, что новые жизненные идеалы и приоритеты находят свое выражение в барочном искусстве.

Однако каким бы точным и убедительным ни был анализ стилей Вельфлина, он остался чисто техническим и не привел к историческому пересмотру эпохи. Таким образом, проблема барокко оставалась открытой.

К началу XX века барокко было признано стилем в искусстве. М. Реймон пишет: «Классицисты являются защитниками принципа авторитарности, традиции, следования формулам; барокко - это свобода» $[5,9]$.

«Если барокко противостоит классицизму как движение - застывшим формам, как свет - тени, как новое - традиционному, как свобода - авторитарности, то почему бы не продолжить систему противопоставлений? Почему не вывести это противостояние из архитектурной области и не сделать барокко одним из двух полюсов художественного созидания вообще?» $[3,25]$. Эта идея прослеживается в работах европейских авторов рубежа XIX - XX веков.

Так, в своей книге «О барокко» (1931) испанский философ Э. д’Орс создает теорию, называемую eоn baroque (барочный дух). В историографии барокко эта книга стала обязательным этапом, несмотря на ученые споры вокруг термина еоn, который может быть переведен как категория или константа (такой менее научный термин предпочитает переводчик

$$
-102-
$$


книги д’Орса на французский язык А. Руар-Валери). Рассматривая различные культурные явления, автор приходит к выводу, что феномен барокко интересен не только для искусства, но и для всей цивилизации. По д’орсу, «...отношение между духом классическим и барочным -это вопрос отношения между Разумом и Жизнью. Эта оппозиция может иметь разные грани: Аполлон - Дионис, порядок - хаос, натура - притворство» [4, 70]. Утверждая, что барокко есть понятие вневременное, так как его проявления варьируют в формах, встречаются в различные эпохи и в разных странах, ученый приходит к выводу, что барокко является стилем культуры и определять его нужно как явление транзисторическое: в зависимости от времени и страны может иметь самые разные вариации и свою собственную схему (например, романтизм д’Орс рассматривает как новую реинкарнацию барокко). Теория д’Орса не получила безоговорочного признания среди историков культуры, многие вопросы оставались открытыми.

Следующий этап в определении термина барокко получает диалектическое движение к ограничению широкого толкования, где стилистическое применение расширяется, а историческое определение сужается. Так, А. Фосийон в книге «Жизнь форм» (1936) определяет барокко как момент жизни форм, наделяя его характерными чертами: «Прежде всего, свобода: формы покидают заданные ограничения, приходят в несоответствие, пытаясь завладеть пространством. Далее, синтез искусств: их корни переплетаются, пересекают границы и заимствуют эффекты друг друга. И, наконец, ностальгия по прошлому: интерес к старым формам, где барокко ищет вдохновение, примеры, опору» [2, 25]. В жизни форм ученый видит определенные этапы, которые можно найти в различные эпохи, в разных стилях: фаза архаизма, или экспериментальная - поиск равновесия и доктрины; классическая фаза - стадия расцвета и порядка; барочная фаза - изысканность, фантазия, развитие, в котором все характерные черты теряются, забывая свои функции, преобладают всяческие украшения, создаются дополнительные детали. «Таким образом, искусство, следующее за Ренессансом, где просматриваются черты оригинальности, изобилия, излишества, заслуживает того, чтобы быть названным барокко, так же как эллинистический период в Греции или пламенеющая готика в искусстве конца средневековья» $[2,28]$.

Тенденция распознавания барокко вне всяких пространственных ограничений была развита в работе «Барочные искусства» (1963) К. Роем. Однако чтобы определить черты барокко «вечного», «транзисторического», по мнению Ж. Руссе, вначале надо выделить референцию барокко «исторического» и, изолировав, изучить его. Ученый пишет: «Доминирующая тенденция локализуется все уже и уже: барокко XVII века можно определить как «классическую» фазу между маньеризмом (поиском равновесия) и рококо (избытком и фантазией)» $[7,125]$. 
Многие исследователи отталкиваясь от теории д’Орса, подчеркивают при этом ее опасность и притягательность. Так, например, В.-Л. Тапье в своей книге «Барокко и классицизм» (1957) дает более точное определение стиля: «Следует отметить, что стиль не заключает в себе лишь технику, не сводится только к виртуозности и мастерству. Это понятие содержит в себе свойства гармонии между художественной формой и жизнью общества» $[8,67]$. Отдавая дань первооткрывателю дискуссий о реабилитации барокко Г. Вельфлину, Тапье вносит нюансы в оппозицию «бароккоклассицизм»: хронологические рамки оказываются более сложными. Ученый выделяет период мирного сосуществования барокко и классицизма, подчеркивая, что их черты могут содержаться в творчестве одного и того же автора.

В 70-80-е годы XX века библиография по изучению барокко становится впечатляющей по количеству и качеству. По мнению современных ученых [2;3;6], барокко как стиль следует рассматривать в двух аспектах: со стороны формальных признаков и как «выразительный символ» реальности культурной, социальной, психологической. Барокко любит роскошные декорации, полные формы, фантазию, красочность. Оно любит движение планов, изогнутых линий, орнаментальные украшения, многоцветность. Все эти определения остаются действенными в разных видах искусств. Примененное к определенной исторической эпохе (конец XVI - XVII век), к географическому пространству (большая часть Европы), к месту рождения (Италия), барокко выражает крупное культурное движение. Его зарождение ученые рассматривают как последствия Контрреформации (иезуитская духовность) и политического абсолютизма. Таким образом, термин барокко может быть распространен на все виды деятельности этого периода (философию, музыку, моду, политику, литературу и т. д.). Эра барокко начинается с конца XVI века и простирается на весь XVII век. Но эти границы могут колебаться, если говорить о «выражении социальном» (В.-Л. Тапье), нужно восстановить человеческую общность во времени, определить тип власти, социальные отношения, связь форм эстетических, чувственных, мыслительных, а также взаимосвязь различных культурных веяний.

Исследования художественного стиля барокко продолжаются и сегодня. В работах Г. Левилэн, П.-А. Рожа, В. Жильбера рассматриваются дискуссионные проблемы, связанные с литературным барокко. Ф. Боссан, создавший в 1977 году во Франции Институт по изучению старинной музыки и танцев, Н. Дюфор, выдающийся профессор истории музыки Парижской консерватории, органист, а также Национальный народный театр (TNP) под руководством Ж. Вилара совместно с учеными-литературоведами пропагандируют это искусство широким зрительским кругам, организовывая выставки и конференции, «круглые столы» и концерты, международные коллоквиумы, поэтические, музыкальные и театральные постановки. Это

$$
-104-
$$


говорит о том, что «литература и искусство роскоши, пышности, ослепительной новизны, а также великие создатели оригинальных и изысканных произведений, оклеветанные и презираемые более трех веков» [7, 252-253], сегодня интересны и востребованы.

\section{Список использованной литературы}

1. Gautier T. Postface aux Grotesques / edite par C. Rizza, Bari, Schena-Nizet, 1985.

2. Guilbert B. Le baroque litteraire francais. - P., 1997.

3. Levillain H. Qu'est-ce que le baroque? - P., 2003.

4. Ors E. d' Du baroque. - P., 1983.

5. Raymond M. Baroque et Renaissance poetique. - P., 1985.

6. Rojat P.-H. Litterature baroque et litterature classique au XVIIe siecle. - P., 1996.

7. Rousset J. Litterature de l'age baroque en France, Circe et le paon. - P., 1953.

8. Tapie V.-L. Baroque et Classicisme. - P., 1980.

\section{Summary}

The article deals with baroque problems in the view of the opinion of European scientists on baroque aesthetics. 